\title{
КОНЦЕПТУАЛЬНІ ОСНОВИ ПРОБЛЕМИ ФОРМУВАННЯ СОЦААЛЬНОЇ АКТИВНОСТІ СТУДЕНТІВ (ДИДАКТИЧНИЙ АСПЕКТ)
}

\begin{abstract}
У статті на основі аналізу досліджень філософської, психолого-педагогічної літератури уточнюються поняття «соціалізація», «сочіальна активність», окреслюеться коло їх теоретичних питань щодо формування сочіальної активності студента, визначається роль соиіуму у формуванні активної соціальної позиції особистості.

Ключові слова: особистість, соціальна активність, сочіалізаџія особистості, соиіум, діяльність особистості, молодь.

В статье на основе анализа исследований философской, психолого-педагогической литературы уточняются понятия "сочиализация», "сочиальная активность», конкретизуются теоретические вопросы относительно формирования сочиальной активности студента, определяется роль социума в формировании активной сочиальной позиции личности.

Ключевые слова: личность, сочиальная активность, сочиализачия личности, сочиум, деятельность личности, молодежь.

In the article on the basis of analysis of researches of philosophical, ïñè̃̂ê̈î̃̂́-pedagogical literature specified concepts "socialization», "social activity», the circle of theoretical questions is outlined in relation to forming of social activity of student, the role of sociuma is determined in forming of active social position of personality.

Key words: personality, social activity, socialization of personality, socium, activity of personality, young people.
\end{abstract}

Загальновідомо, що навчальний процес не обмежується замкненим колом наукових знань. Навпаки, саме навчання, набуття широких життєвих знань, що активно засвоюються, і $є$ основою, на якій формується і розвивається активна життєва позиція школяра, а згодом студента. Оскільки навчальний процес систематичний, повсякденний, послідовність його запрограмована, він може і повинен прогнозувати широку соціальну мету формування особистості і ії стрижневих властивостей.

Зв'язок навчання 3 життям - найважливіший канал формування активної соціальної позиції студента. Молодь повинна бачити роль науки для перетворення практики, розуміти, що сучасна наука - рушійна сила матеріального життя людини, суспільства. Через призму навчальних дисциплін студенти повинні бачити сучасність і своє місце в ній.

Проблема формування активної соціальної позиції цікавила багатьох учених ще за радянських часів, проте залишається недостатньо дослідженою і дотепер. Цій проблемі приділяли увагу С. Бондаревська, А. Макаренко, В. Сластьонін, С. Шацький. Пізніше досліджували соціальну позицію особистості $\quad$ В. Андреєв, Ю. Бабанський, I. Лернер, Г. Щукіна та інші. Гуманізації навчального процесу та вихованню соціально активної особистості приділяють свою увагу вчені А. Бабаєв, В. Бездухов, Л. Коханович, В. Радул, С. Стрельникова.

Meта статmi - проаналізувати концептуальні основи проблеми формування соціальної активності студентів на предмет актуалізації дидактичних можливостей стимулювання цього процесу.

Підвищена мобільність молоді, іï специфічна позиція в суспільстві та здатність наслідувати досвід усього людства дозволяють використовувати інноваційний потенціал молодого покоління для вдосконалення сучасного суспільства. 3 цієї причини соціальний розвиток молоді має бути керованим процесом, що не передбачає маніпулювання їхньою свідомістю, а має на меті створення необхідних умов, добір ефективних засобів, що забезпечують успішну соціалізацію у процесі навчання й виховання сучасного молодого покоління.

Соціалізація є одним із найважливіших педагогічних понять. На думку В. Андреєва, соціалізація відбувається за допомогою двох видів діяльності: соціального навчання й соціального виховання. Зміст процесу соціалізації вчений вбачає в оволодінні людиною різноманітними соціальнорольовими функціями, але за умови, що соціалізація несе позитивний заряд і іï результати будуть соціально значущими і схвалені суспільством. За В. Андреєвим, соціалізація особистості - це процес і результат двох взаємодоповнюваних видів діяльності соціального виховання й соціального навчання з метою оволодіння соціально-рольовими функціями життєдіяльності особистості та ії̈ самореалізації в соціумі [2, с. 218].

Світоглядні основи закладаються поступово. Цьому процесу треба приділяти особливу увагу. Планування викладачем навчального матеріалу передбачає розв'язання питань: Які ідеї можна викласти? У якій формі розкрити? Якими доказами обгрунтувати? На які внутрішні процеси пізнавальної діяльності спиратися?

Активна життєва позиція неможлива без формування активності самої людини з раннього віку. Властивість активності як риси особистості складається в діяльності різноманітного плану (пізнавальної, трудової, суспільної). Самоналаштування на навчання - внутрішня психологічна пружинка, що сприяє формуванню активної позиції особистості. У цьому сенсі основою сучасного процесу навчання $є$ розвиток самостійності студентів, опора на їхню самостійну діяльність. 
Викладачу не можна налаштовувати себе на «проходження програми», головний його орієнтир активна позиція студентства в навчальному процесі [3, с. 34].

Особистості притаманні обов'язкові соціальні якості: індивідуальність, відповідальність, характер, темперамент, самоконтроль, самоаналіз, воля, цілеспрямованість, активність. У структурі особистості виокремлюють чотири рівні, або підструктури, де соціальну детермінацію особистості представлено на третьому й четвертому рівнях: 1) біологічно зумовлена підструктура, до якої входять темперамент, статеві, вікові властивості психіки; 2) психологічна підструктура, що включає індивідуальні властивості окремих психічних процесів, що стали властивостями особистості пам'яті, емоцій, мислення, відчуттів, сприймання, почуттів і волі; 3) підструктура соціального досвіду, до якої входять набуті людиною знання, уміння, навички i звички; 4) підструктура спрямованості особистості, яка передбачає ряд взаємопов'язаних підструктур: бажання, схильність, ідеали, інтереси, індивідуальна картина світу і вища форма спрямова-ності - переконання [3, с. 37].

Людина 3 народження входить до різних соціумів і виконує в них певні соціальні ролі, зумовлені цінностями певного соціуму. Кожне нове покоління засвоює досвід попередніх у вигляді соціальних цінностей і ролей. Це наслідування має системно-рольовий характер [3, с. 35]. Перебуваючи в цьому світі, людина виконує не окремі ролі, а систему соціальних ролей, оскільки наше життя побудоване у вигляді системи соціумів з їх цінностями і ролями, тобто щоб бути повноцінним членом суспільства, індивід повинен бути здатним виконувати різноманітні соціальні ролі. Отже, особистість - це така соціальна якість конкретної людини, що виявляється рівнем засвоєння і виконання системи соціальних ролей. Саме через засвоєння соціальних ролей певних соціумів людина стає особистістю.

У більшості концепцій галузей знань визнано тезу про те, що активність розглядається 3 виокремленням іiі провідних характеристик 3 позиції певної науки. У філософії активність особистості та діяльність представлено як способи безпосереднього існування, розвитку людини та їі особистості, оскільки лише в діяльності людина входить до системи суспільних відносин і організовує свою поведінку 3 іншими людьми. У соціальній психології активність також розглядається в нерозривному зв'язку з діяльністю особистості. Соціальна педагогіка визначає активність як одну з найважливіших соціальних якостей особистості, у структурі якої виокремлюють внутрішню активність свідомості і зовнішню практичну діяльність, яка виявляється в пізнанні обставин об'єктивної дійсності й оцінці цих обставин.

Педагогічний словник розглядає активність особистості (віл лат. activus - діяльнісний) як діяльнісне ставлення особистості до світу, здатність виробляти суспільно значущі перетворення матеріального і духовного середовища на основі засвоєння історичного досвіду людства. Активність особистості виявляється у творчій діяльності, вольових актах, спілкуванні, формується під впливом середовища і виховання.

Провідні сучасні вчені виокремлюють такі види активності особистості: активність надситуативна, активність пізнавальна, активність суспільна, активність соціальна. Більш детально зупинимося на понятті «соціальна активність».

Активність соціальна - це родове поняття відносно суспільно-політичної, трудової, пізнавальної та інших видів активності. Соціальна активність реалізовується у вигляді суспільно корисних дій під впливом мотивів і стимулів, в основі яких лежать суспільно значущі потреби. Суб'єктом - носієм соціальної активності є людина, соціальна група та інші спільноти. Як суспільна властивість особистості, активність соціальна розвивається через систему зв'язків людини з навколишнім середовищем у процесі пізнання, діяльності та спілкування. Соціальна активність як динамічне утворення може мати різний рівень вияву. Певний рівень соціальної активності залежить від співвідношення між соціальними обов'язками особистості в суспільно значущій діяльності та суб'єктивними настановами на діяльність [4, с. 147].

У формуванні активної життєвої позиції студента значну роль відіграє пізнавальний інтерес. Опора навчального процесу на інтереси і схильності завжди сприяє налаштуванню на навчання, де закладаються основи активної позиції.

До прийомів, які спонукають студентів займати активну позицію у процесі навчання, можна віднести такі ситуації:

-ситуації, у яких студент аргументовано доводить свою думку, наводить факти, використовує знання і досвід;

- ситуації, що спонукають студента заглиблюватися в осмислення знань;

- допомога одногрупнику при утрудненнях, роз'яснення незрозумілого;

-спонукання до пошуку декількох варіантів розв'язання поставленої задачі;

- вільний вибір завдань, переважно пошукових і творчих;

- створення ситуацій обміну інформацією між студентами;

- ситуації самоперевірки, аналізу власних пізнавальних і практичних робіт.

Звернемося до робіт дослідників соціальної активності особистості, які визначили засадничі аспекти змісту даної проблеми.

Соціальна активність молоді, як зазначає В. Терлецький, $є$ рисою життєдіяльності, яка розвивається і має своєрідну логіку в основних групах молоді залежно від загального процесу 
життєвого самовизначення. Активність є однією 3 конституювальних характеристик діяльності людини, що показує їі здатність до саморозвитку, саморуху шляхом ініціювання цілеспрямованих продуктивних предметних дій [1, с. 129].

На думку А. Петровського, активність є умовою існування живих організмів у світі, реалізацією потреб особистості. До видів соціальної активності Р. Немов відносить спілкування, гру, навчання і працю, що розглядаються як основні види діяльності людини [1, с. 130].

Науковець В. Бочарова вважає, що саме через організацію форм і засобів спілкування в соціумі передаються знання, способи діяльності, норми поведінки, утворюються резерви для розвитку системи ціннісних відносин особистості, - перш за все, іiі соціальної активності, яка є суспільною якістю людини та розвивається тим інтенсивніше, чим більший простір для ініціативності, самостійності, самодіяльності, елементів творчості, чим різноманітніші зв'язки і спілкування індивіда, чим частіше він перебуває в ситуації вибору, прийняття рішень [4, с. 151].

Отже, соціальна активність - це особистісна якість людини, що визначається як характеристика їі мотиваційно-ціннісної орієнтації і самоорганізації, її соціально спрямованої діяльності та поведінки. Показниками соціальної активності є вияв ініціативи і відповідальності, самостійність і незалежність, комунікабельність і безконфліктність у спілкуванні, прагнення надати допомогу і підтримку людям, винахідливість і творчість. Соціальна активність розглядається як одна 3 найважливіших умов соціалізації особистості у процесі виховання, навчання і самовиховання, під час якого людина усвідомлює себе в суспільстві як особистість. Результатом цього є засвоєння соціальних норм i цінностей, на основі яких формуються якості особистості. Це поведінка у побуті, мова, здатність до творчості, сприйняття і засвоєння культури свого народу [5, с. 148].

В умовах інтенсивних соціальних перетворень зовнішні умови, що визначають розвиток особистості, піддаються змінам. У зв'язку 3 цим усвідомлення особистістю суспільних явищ зумовлює чітке уявлення про цінності, що функціонують у суспільстві, оскільки в них акумульовано культурне багатство народу. Виявлення таких цінностей і розуміння їх соціальної значущості $\epsilon$ досить складними процесами для молодого покоління. Важливу роль при цьому відіграє активність не лише на конкретному занятті, а і в самому процесі пізнання, оскільки знання, отримані без аналітико-синтетичної роботи, формальні та зумовлюють зміни процесів, пов'язаних із творчим виявом свідомості.Отже, активність виявляється в самому процесі мисленєвої діяльності та іiі пошуковій спрямованості.

У будь-якій сфері діяльності того, хто вчиться, значна роль відводиться педагогу, який повинен надати можливість учневі самостійно зробити вибір дій і прийняти відповідальність за їх виконання. Педагог, який має професійні уміння, допоможе визначити об'єкт, на який буде спрямовано діяльність учня, максимально сприятиме виявам пошукової активності для вибору оточення, яке б забезпечило самовираження і самореалізацію, враховуючи той факт, що зростання активності особистості перебуває в залежності від культури суспільних відносин, що визначають загальний рівень і характер розвитку в людині суспільного. Рівень соціальної активності залежить від співвідношення між обов'язками особистості в суспільно значущій діяльності і суб'єктивними настановами на діяльність та ставлення до неї.

Подальший прогрес людства неможливий без активної діяльності його членів. Одним із найважливіших показників якості життя $\epsilon$ соціальна активність особистості, яка дозволяє реалізовувати життєвий потенціал. Соціальна активність формується і розвивається під впливом зовнішніх сил, а також завдяки внутрішнім силам людини. Пробудження таких сил, подолання соціальної пасивності $\epsilon$ метою сучасної системи освіти. Цілеспрямована взаємодія педагога i студента в навчальному процесі дозволяє формувати соціально активну особистість.

Підсумовуючи, зазначаємо, що ступінь розвитку соціальної активності та їі інтенсивність багато в чому зумовлені позицією людини до основного виду діяльності, до якої вона залучається як громадянин. Цей вид діяльності передбачає оволодіння соціально важливими обов'язками, формує самосвідомість, визначає самооцінку. У юнацькому віці відбувається перетворення активності як природної властивості на соціальну систему потреб та інтересів у процесі пізнання суспільних явищ.

Уважаємо, що сучасний процес навчання у виші можна цілеспрямовано організовувати 3 орієнтацією на формування активної соціальної позиції студентів через створення відповідних дидактичних умов, прийомів та засобів, які б спонукали студентів до активної самостійної, пізнавальної діяльності і, як наслідок, активної соціальної діяльності. Задля цього потрібно зміст навчання гуманітарних дисциплін переорієнтувати на такий, який би забезпечував максимально можливі умови для ефективного формування активної соціальної позиції студентів.

1. Вольфовська Т. О. Способи і моделі соціальної взаємодії в соціальних уявленнях молоді / Т. О. Вольфовська // Соціальні уявлення молоді: особливості та шляхи формування / за ред. І. В. Жадан. - К., 2007. - 280 с. 2. Гнатенко С. Л. Виховання громадянськості на заняттях з гуманітарних дисциплін / С. Л. Гнатенко // Вісник Львівського університету. - 2005. - № 19. - С. 216-221. 3. Кузнєцова І. До питання про процес соціального становлення людини: індивід - індивідуальність - особистість / І. Кузнєцова // Шкільна бібліотека - 2005.- № 12. - С. 34-38. 4. Семашко О. М. Соціологія молоді. Проблеми соціалізації молоді засобами культури / О. М. Семашко // Соціологія культури : [навч. посіб.] / за ред. О. М. Семашка. - К., Львів, 
2000. - 320 с. 5. Щукина Г. И. Активизация познавательной деятельности учащихся в учебном процессе : [учеб. пособие для студ. пед. ин-тов] / Г. И. Щукина. - М. : Просвещение, 1979. - 160 с. 